write over, the instructions of another. Interactions between creatures occur because one can make use of the instructions of another, just as a virus can make use of the gene products of the cell, or of other viruses. It is interesting, however, that there is no distinction between genotype and phenotype: in this it resembles an RNA world.

What can such a study tell us about biology? There is a danger that, in Boyd and Richerson's words ${ }^{5}$, we shall replace a world we do not understand by a model of the world we do not understand. Ray could reply that one can do experiments in his world more easily than in the real one. And we badly need a comparative biology. So far, we have been able to study only one evolving

\section{Cold comfort in the greenhouse}

\section{Jeffrey T. KiehI}

MAN-MADE chlorofluorocarbons (CFCs) are important not only for the part they play in ozone destruction. They are also greenhouse gases, letting through shortwave solar radiation, but trapping longwave radiation from the Earth's surface and lower atmosphere. So it may be with a false sense of relief that readers learn on page 810 of this issue ${ }^{1}$ that the reduction of greenhouse forcing that follows from ozone destruction (ozone is another greenhouse gas) almost offsets the increase from the presence of CFCs. But put in this globally averaged way, the result ignores the complexities that dog the climate system.

Concerns with the environmental effects of CFCs were first raised in the mid-1970s, when it was suggested ${ }^{2}$ that man-made chemicals such as CFCs could efficiently destroy ozone in the upper stratosphere, $12-50 \mathrm{~km}$ above the Earth's surface. The modelled effects of increased CFCs also indicated an associated increase in lower-stratospheric ozone, due to what was termed the self-healing process ${ }^{3}$ : the depletion at higher altitudes allows solar radiation to penetrate further into the stratosphere, promoting ozone-forming photochemical reactions.

Since this early work, the study of stratospheric ozone depletion has been punctuated by theoretical and observational surprises. Foremost among these was the discovery, in 1985, of the Antarctic ozone hole ${ }^{4}$. This depletion, which is linked to the presence of ice clouds in the lower polar stratosphere, was not predicted in any chemical model. The most recent observations indicate that over the past decade (1979-1990) significant depletions have occurred at mid- and high latitudes in the lower stratosphere. In this region of the stratosphere, ozone tends to warm the atmosphere locally through both shortwave and longwave radiative processes. With the addition of CFCs and the concomitant depletion of ozone, three important changes occur. First, there is less ozone available to absorb solar radiation and warm this part of the atmosphere. This leads to a cooling of the lower stratosphere. Second, the reduction in ozone in the lower stratosphere allows more solar radiation to penetrate into the lower atmosphere, or troposphere, which warms the Earth's system and we cannot wait for interstellar flight to provide us with a second. If we want to discover generalizations about evolving systems, we will have to look at artificial ones. Ray's study is a good start.

John Maynard Smith is in the School of Biological Sciences, University of Sussex, Brighton BN1 9QG, UK.

1. Ray, T. S. in Artificial Life II, Santa Fe Inst. Studies in the Sciences of Complexity, Vol. XI (eds Langton, C. G., Taylor, C., Farmer, J. D. \& Rasmussen, S.) C. G., Taylor, C., Farmer, J. D. \& Rasmussen, S.) 1991)

2. Holland, J. H. Adaptation in Natural and Artificial Systems (University of Michigan Press, Ann Arbor, 1975).

3. Eigen, M. Naturwissenschaften 58, 465-523 (1971)

4. Maynard Smith, J. Nature 225, 563-564 (1970).

5. Boyd, R. \& Richerson, P. J. Culture and the Evolutionan Process (University of Chicago Press, 1985). surface. This effect actually increases the warming potential of the CFCs. Third, the reduction of ozone and the cooler lower stratosphere results in less emission of longwave radiation down into the troposphere. This leads to a cooling of the surface-troposphere system. It is the third process that results in the cancellation of the direct greenhouse effect of the CFCs.

But these findings do not imply that the increasing quantity of CFCs in the atmosphere is not a problem. Although there is a global cancellation of the CFC warming potential, the magnitude of the negative forcing depends upon latitude, owing to the latitudinal variation in ozone depletion. The negative forcing, then, is largest at mid- and high latitudes, and weakest at the Equator. The latitudinal distribution of the total greenhouse warming effect due to $\mathrm{CO}_{2}, \mathrm{CH}_{4}$, $\mathrm{N}_{2} \mathrm{O}$ and CFCs thus decreases more sharply at mid- to high latitudes when the indirect ozone effect is included. The predicted greenhouse forcing for the period 1979-90 decreases from a tropical maximum of $0.5 \mathrm{~W} \mathrm{~m} \mathrm{~m}^{-2}$ to a polar minimum of $0.3 \mathrm{~W} \mathrm{~m}^{-2}$ with no ozone effect. The ozone depletion in fact slightly increases the tropical forcing, but reduces the polar forcing to nearly zero. Thus, the latitudinal gradient of the greenhouse forcing is more than doubled by the inclusion of the lower stratospheric ozone forcing. This strong increase in the gradient of greenhouse forcing could have important dynamic effects. In the present work, Ramaswamy et al. use models that fix dynamical feedback effects, and they point out that general circulation models will be needed to address any dynamical issues.

The new results show that stratospheric ozone continues to surprise atmospheric scientists. It would be wrong to conclude from them that CFCs are a benign component in global warming. Indeed, these findings indicate how intimately coupled is the chemistry of the stratosphere to the climate response at the Earth's surface. From the past 20 years of ozone studies, it seems that the only thing that is not surprising about this facet of the climate is that it will keep surprising us.
Jeffrey $T$. Kiehl is at the National Center for Atmospheric Research, PO Box 3000 , Boulder, Colorado 80307, USA.

\footnotetext{
1. Ramaswamy, V., Schwarzkopf, M. D. \& Shine, K. P. Nature 355, 810-812 (1992).

2. Molina M. J \& Rowland, F. S. Nature 249,810-812 (1974)

3. WMO/UNEP Global Ozone and Monitoring Project, Report No. 18 (Worid Meteorological Organisation, Geneva, 1988)

Farman, J. C., Gardiner, B. G. \& Shanklin, J. D. Nature 315, 207-210 (1985).

5. WMO/UNEP Scientific Assessment of Stratospheric Ozone Depletion, 1991 (World Meteorological Organisation, Geneva, in the press).

6. Ramanathan, V. Science 190, 50-52 (1975).
} 